\title{
Ruwatan Ritual of Dreadlocks Haircut: Negotiation Between Cultural Identity and Cultural Innovation in Contemporary Dieng Plateau Community
}

\author{
A Luthfi ${ }^{1}, \mathrm{~K}$ B Prasetyo ${ }^{2}$, N Fatimah ${ }^{3}$, E Pularsih $^{4}$ \\ 1,2,3 Department of Sociology and Anthropology, Universitas Negeri Semarang \\ ${ }^{4}$ SMA Takhassus al Qur'an, Wonosobo
}

\{asma_luthfi@mail.unnes.ac.id ${ }^{1}$, mrbayu@mail.unnes.ac.id ${ }^{2}$, fatimahnurul8@mail.unnes.ac.id ${ }^{3}$, ekapularsih@gmail.com ${ }^{4}$ \}

\begin{abstract}
This Dieng Plateau Society is a community group in Central Java that has a belief about the existence of dreadlocked children as Descendants of Kyai Kolodete. Ruwatan ritual of dreadlocks haircut individual are rituals that are performed to keep the dreadlocked children from the influence of evil spirits. In the past, this ritual was matched to the children's weton. But nowadays, the dreadlocks haircut are integrated into the annual cultural festival of Wonosobo Regency, Carried out communally and no longer based on the children's weton. This study aims to explain the struggle between cultural identity contested by local people and cultural innovation initiated by local Governments in order to promote the cultural tourism in Wonosobo Regency. This study uses qualitative research methods with observation, interviews, and document studies as a tool for collecting data. Data processing is done in four steps roomates are the data collection, data reduction, a data display, and conclusion. The results of the study show that: (1) the beliefs of the Dieng Plateau community about mythic elements from dreadlocked children are still strongly embraced even though the procession of ruwatan ritual of dreadlocks haircut has been changed due to adaptation for tourism interests. (2) Cultural identities and cultural innovations in the ritual of dreadlocks haircut ruwatan communally involve; different actors and different orientations so that both can be done According to Reviews their own interests. (3) The existence of cultural innovation brings changes slowly to the perspective and behavior of the community about the existence of rituals roomates are no longer Merely sacred dimensions.
\end{abstract}

Keywords: Cultural identity, Cultural innovation, Dreadlocks haircut, Ritual.

\section{INTRODUCTION}

In the era of globalization, society and culture change so quickly in line with the increasing mobility of society and development of information technology. The movement of people who navigate the space and place in a very short time make cultural contacts between a person or a group of people with other social groups else going on almost every second. This resulted in the intersection between two different cultures becomes increasingly rapid and intense. 
Adaptation and accommodation of foreign cultures is inevitable with the strengthening of traffic information through information technology is so sophisticated. Social media is currently a new arena for people to socialize, is a vehicle for the spread of cultural values, so that the boundaries of culture have become blurred. Abdullah explains that the process of globalization has drawdown limits of culture to form a borderless society[1]. With this condition, people do not just practice the original culture but also adopt a foreign culture [2]. If the values are outside the culture which was adopted with a very strong and dominant, it will result in homogeneity in the behavior and practices of public culture.

Homogenization of culture is really a threat to the existence of local culture when local people take for granted the values of the incoming foreign perform filtering without value. If so, these local values can be uprooted from their cultural roots and dissolve in the current global values [3]-[5]. But conversely, if the local culture with a series of strategies that do are capable of playing its role in receiving and reproducing the global values, the existence of the local culture can still be maintained [6], [7] .

Thus, the implications of globalization in the form of the uniform cultural practices are not fully occur in the whole world. [8] in his concept of "disjuncture" explained that globalization does not give birth to a single global space, but spawned several different spaces that can be categorized into; (1) ethnoscapes (space of human movement), (2) financescapes (space movement of money), (3) Ideoscapes (space movement of images and political ideologies worldwide), (4) mediascapes (space moving image through various media), and (5) technoscapes (space movement of information through technology to the rest of the world). Through these spaces, global values are homogeneous will experience the diversity of shape when in contact with a distinctive and unique local culture.

People living in their generic culture have local values and traditions which are binding and still they practiced. This is because the culture still providing functionality in their lives. When the process of globalization, the case, then it may cause friction who gave birth to a wide range of responses from the local community [9]. There adopting it as a whole, there were adapting to local values they have, but others do resistance on the global values. This phenomenon can be seen in cultural practices undertaken by various communities, one of them on the Dieng plateau is still very strong with the local culture. Through the tourism industry and the development of information technology is so fast, people plateau Dieng try to accommodate the local culture they have with the tourism industry.

One of the cultural activities that are still carried out by public Dieng Plateau is the ritual of shaving ruwatan dreadlocks. Children dreadlocked believed by society as a surrogate Dieng plateau Kyai Kolodete, local leaders who are considered public supernatural powers. So that these children are not overshadowed by Kyai Kolodete spirit, then they must be cleared through the ritual shaving ruwatan dreadlocks. Its execution time is usually carried out in accordance with Weton finasal ability of the child and parents to grant the request of the child. Along with the influx of tourism in the Dieng Plateau, shaving dreads getting attention by the public and make them interested to see the cultural procession once traveled to Dieng Plateau.

With the tourism potential of cultural activities that can help increase Regional Original Revenue (PAD), Wonosobo regency government held an annual cultural festival which included ritual ruwatan of dreadlocks haircut. The reason is the inclusion of cultural activities in the annual cultural festival circuit, because this ritual considered the hallmark of the Dieng plateau communities that are not found in other places. However, the annual cultural festival that already have a fixed schedule, sometimes do not coincide with the time Weton (day of birth) dreadlocked child, so they are compared with no longer based on their weton. This is what creates a shift in the procession ruwatan dreadlocks haircut ritual. On the one hand 
society Dieng plateau innovation culture through tourism, but on the other hand, they still maintain their local values as cultural identity. This article will explain the resonance that occurs in Dieng society in relation to the struggle between cultural innovation and cultural identity in the ritual of dreadlock dreads.

\subsection{Research Method}

This study used a qualitative research method that has resulted in the description of the form of words written or spoken of people and behaviors that can be observed [10]. The research location is in Dieng Wonosobo or more people know him as Dieng Wetan. The subjects were traditional figure and some families of children dreadlocked been included in ruwatan of dreadlock haircut. Informants in this study is the Department of Tourism and Culture and society in the Dieng Plateau. Data collection using observation, interview and documentation. (1) observation is the data collection techniques with direct observation of the object under study is called the observation, (2) The interview is a technique of collecting data to get the information extracted from the data source directly through conversation or frequently asked questions, (3) documentation used to complete the data in the study. Documentation collected at the time of or after the study in the form of photos, videos. The validity of research data obtained by triangulation data. Triangulation is achieved by comparing the data obtained through berbeda. Data analysis technique in this study include (1) The collection of data, (2) data reduction, (3) presentation data, and (4) conclusion or verification [11].

\subsection{Result and Discussion}

\subsubsection{Belief and Rituals Activities Dieng Society of Dreadlocked Child}

Public perception of the Dieng plateau against children dreadlocked as a blessing and problems [12], [13], can not be separated from their belief in Kyai Kolodete. For the people of Dieng, Kyai Kolodete not only as a Hindu spiritual leader whose descendants are scattered in the region, but also believed to be baureksa (ruler or guard) and dhanyang (protector) society Dieng [14]. Dreads possessed by some children in the Dieng plateau is considered as a surrogate Kyai Kolodete, because he also has dreadlocks during his lifetime.

Dreadlocks hair growth in certain children in Dieng started since they were aged 40 days to 6 years are characterized by a high heat temperature, seizures, and fainting spells, despite being medically treated modern. Shortly thereafter, the clot grows hair (dreadlocks) on their heads and the disease will merede along with the growing dreads perfectly. During this dreads unshaven, Dieng people believe that these children will be kept up-plagued by Kyai Kolodete spirit and will be used as food Batarakala (giant who has a scary face). To release the child dreadlocks of the disorder, then they should diruwat. Ruwat derived from the word ruwat (rumuwat) or mangruwat which means making no power, remove curse, remove misfortune, stains and other [15]. Before the ruwatan of dreadlocked, parents must comply with all requests of the child (bebono) such as bicycles, chickens, goats or other goods. There was also a request made quite burdensome parents and cost a lot. However, the request should be executed because if parents do not comply with the request of the child, then the gimbelnya hair will grow back.

Ruwatan dreadlocks haircut ritual usually can only be implemented after the child dreadlocked specific requests to be met or if it has been aged 6-7 years or after a period of 
'pupak' ie after the child's milk teeth grow. By acculturating the local culture with the teachings of Islam, the shaving of dreadlocks is carried out based on the child's weton. Shaving procession led by traditional leaders, community leaders who understand the process, or a person designated by the child. Activities include the provision of ritual offerings, procurement bebono (object request of the child), shearing, and dreads pelarungan [14].

\subsubsection{Procession of Ruwatan Dreadlocks Haircut Rituals at the Wonosobo Annual Culture Festival.}

As a cultural activity, dreadlocks ruwatan ritual is done routinely in which almost every year there are children who will cut his/her hair. Ruwatan dreadlocks shaving ritual is usually done on an individual basis depending on the readiness of the child's parents. However, along with the incessant incoming tourism industry in the Dieng plateau, cultural activities have also become an attractive tourist commodities, in addition to nature and religion. Department of Tourism and Culture is the main pioneer of inclusion ruwatan Barber Mass Gimbal the agenda today so Wonosobo, precisely on 24 July each year. Search dreadlocked child usually begins in the two previous months were made possible by a partnership with the District of Indigenous People. After data collection is done, recently been some kids who really ready included in ruwatan Mass of dreadlocks haircut. This happens because not all children dreadlocked there can be included in this ritual. Children who participated in the Mass ruwatan Barber Dreadlocks are children who are already ready in terms of requirements such as the demand of the child and is willing to both the children and parents.

Ruwatan Dreadlocks haircut was integrated into the annual cultural festival is held in bulk, where ordinances and does away with ruwatan offerings are done individually. However, the time specified by the local government led to a lot of children who attend Mass ruwatan dreadlocks haircut and having Weton (the day of birth) different are did on the same day. This is because the local government is willing to adjust with the anniversary of Wonosobo. It provides little change in the manner in which the tradition usually done by people Dieng Plateau.

To anticipate this, traditional leaders as a responsible implementation this ruwatan visit ancestral graves dreadlocks namely Kyai Kolodete to ask permission first. He asked that whenever implementation ruwatan of dreadlocks haircut that do not use Java calculation in choosing its implementation time can keep running smoothly. In this case there is a process of negotiation between traditional leaders by Kyai Kolodete spiritually.

In addition, when ruwatan Mass if dreadlocks haircut implemented in a majority of the people are Muslim, are not usually allowed to burn incense or other rituals that are considered idolatrous by them. The decision is understood and appreciated by Indigenous leaders, but leaders also did not leave the customary rituals. Indigenous leaders anticipate it by performing the ritual itself first at home before the procession ruwatan Mass Gimbal Barber.

Before this ritual started, first performed pilgrimage and pilgrimages to several shrines in the Dieng Plateau, including the grave of his wife Kyai and Nyai Kolodete Cindelaras Mount Kendil with the intention of seeking permission for the event to run smoothly. Shrines else is hermitage Mandalasari, Mount Bismo, Mount Pakuwaja, Crater Sikidang, Hindu temples, Ponds Balekambang, Spring Maerakaca, Wells Jalatunda, Crater Candradimuka, Sileri Crater, Mount Prau, Kali Write, tomb Grandmother Manggalayuda and tomb Grandmother Kyai Carita. In the evening held jamasan heritage or heirloom wash owned traditional leaders such as ring Buton and clippers to shave dreads which would then be taken during the next day cultural carnival. 
Cultural Carnival began around $08.00 \mathrm{pm}$ from the gate of tourist attractions then surrounds the area or village around the tourist spot. This cultural carnival is not part of the ritual, but an additional event aimed at accompanying the departure of dreadlocked children before undergoing ruwatan. The implementation of this cultural process is fully funded by the government of Wonosobo Regency, with a budget of Rp.100,000/person and Rp.1,500,000 / group used to fulfill carnival, consumption and transportation equipment. In the procession there are carrier forces and various cultural arts from the surrounding community.

Cutting dreadlocks on ruwatan Mass did not do traditional leaders but by the Regent, Vice Regent or officers below. Custom figures only assisting and advising. This was done as a tribute to Wonosobo District officials for attending to see Ruwatan Bulk Dreads. One by one the children dreadlocked turn to cut, cut hair is matted hair, while the matted hair did not participate cut. After the procession of cutting dreads is complete, the request for the child will be given and all the dreadlocks that have been cut will be washed away to the water stream of lake or Serayu river.

Although local governments and indigenous leaders have done a culture of innovation through the tourism industry, but people still maintain their cultural identity while running multiple tools and components rituals. As a means of ritual that still they use, among others: first, Tumpeng Robyong, the cone of white on it plugged in a variety of side dishes and snacks such as bananas, flowers rocking, diamonds, sticky rice, milk, chicken, opaque, crackers, boiled eggs, krecek, rengginang, tofu and tempe. As well as the type of food the small depends on the ability of having a livelihood. But all kinds of food cooked and served to the guests there must be a dihiaskan on Robyong cone. Tumpeng dreads Robyong a symbol dedicated to Kyai Kolodete. This cone mean that life is always surrounded by nature invisible life. In order to escape the disturbance, robyong cone offerings must be made to protect the dreadlocked child from stealth grip so that they can develop as children naturally.

Second, Tumpeng necklace which is a white cone decorated coconut necklace. This cone is a symbol of the end ruwatan dreadlock haircut. The meaning of cone necklace is dreadlocked children who have gone through the Ruwatan process will continue the struggle for life and always devote to parents, teachers, and the government and to the Almighty God. Thirdly, white Tumpeng which is a cone made using coffee or savory rice. White cone is presented without any decoration so that all white. The white on rice describe holiness in Javanese tradition. The white cone symbolizes safety for the child who will diruwat. Fourth, yellow Tumpeng which is a cone made from ordinary rice and glutinous rice which is then given turmeric for creating the yellow color of the cone. Yellow cone at present without any decoration as a white cone. Yellow cone symbolizes honor and tribute to the Prophet Muhammad.

In addition to various kinds of cone, the other ritual tool is Ingkung chicken, the chicken is cooked intact after cleaning the outside and inside. Ingkung chicken must come from roosters. This means that the living should clean outside and inside so throughout his life to see true happiness. Another ritual tool is traditional snacks, which are various types of snacks that are usually sold on the market and commonly requested by small children. This Sesaji means hope that after an adult someone is no longer like a child. This offering means hope that after an adult someone is no longer like a child, but can live independently and become a role model or role model. Full drinks intended are tea, coffee, water and others. This offering symbolizes the devotion of posterity to pundensari who is the messenger of God in mastering the universe and is always ready to create common prosperity (memayu hayuning bawana).

The ritual tools that are not less important are the larvae offerings which are objects used to dissolve dreadlocks that have been cut. The offerings float consists of a variety of flowers 
are red roses as a symbol of courage, white roses as a symbol of purity, Kanthil as a symbol always be remembered (kumanthil), ylang as a symbol to be memorable in his life, cempaka as a symbol of happiness, gardenia as a symbol to remind people to always introspection self (introspection) and jasmine symbolizes hope to achieve good names.

\subsubsection{Innovation Culture and Identity in Rituals Ruwatan of Dreadlocks Haircut}

The series of processions of the dreadlocks ruwatan dreadlocks haircut ritual which was included in the annual cultural festival was a breakthrough from the local government of Wonosobo Regency. Through this annual cultural festival, the charm of nature and culture in Wonosobo regency may be exposed properly so as to attract visits from local and foreign tourists. Besides impact on increasing revenue (PAD), these breakthroughs also have an impact on public revenue enhancement and preservation of local culture.

The integration of culture into the tourism industry which currently occurs in the ruwatan shaving dreads is actually a manifestation of cultural innovation in the era of globalization. Millennial tendency for people who prefer to spend their time traveling and visiting places far from city make nature tourism program into something very interesting. In this context, the ritual shaving ruwatan dreadlocks are packed in a package into an attractive treat for travelers. They do not have to wait quite a long time to enjoy cultural activities with one another, but can enjoy several attractions at the same time just a few days.

Creative efforts is indeed quite effective in preserving the local culture, because of government assistance making the community more enthusiastic to always carry it out [16]. Their engagement to local culture and the mystical beliefs of children's dreads makes them always carry out ruwatan shaving dreads in order to get safety. The public need to be ritual Dieng is correlated with the needs of local governments to increase local income through the tourism industry. In this context, a ritual performed no longer represented their identity alone, but also accommodate the interests of tourism industry, so that he suffered several changes, such as the implementation time and ceremonial sacredness. Ritual was originally a private space that connects humans with supernatural agent, turned into a public space that correlate between the owner of the recipient culture and entertainment from that culture. Ruwatan dreadlocks shaving ritual is no longer only as an activity that is worth transcendence, magical, and sacred but also a precious commodity secular and profane.

\section{CONCLUSIONS}

Globalization affects human life in all aspects make their innovation made by the community to the local culture they are not eroded by the global culture. In the context of contemporary society Dieng, cultural innovation is achieved by integrating several cultural activities, including the ritual of shaving ruwatan dreadlocks into an annual cultural festival travel packages Wonosobo. In this cultural festival, there is a ritual that turns some are still maintained. In addition, the actor ritual that once only done by the family and traditional leaders, today added to the role of regent or vice-regents further confirmed the existence of this ritual as a promotional event. Ritual processions and tools are still maintained shows the community as the owner still wants to maintain their cultural identity and its sacredness, although it has experienced a shift in meaning. Here it can be seen how the cultural identity must compromise with innovation cultures do for the sake of tourism. 


\section{REFERENCES}

[1] I. Abdullah, Konstruksi dan reproduksi kebudayaan. Pustaka Pelajar, 2006.

[2] J. Olivier, M. Thoenig, and T. Verdier, "Globalization and the dynamics of cultural identity," J. Int. Econ., vol. 76, no. 2, pp. 356-370, 2008.

[3] S. Suneki, "Dampak Globalisasi terhadap Eksistensi Budaya Daerah," CIVIS, vol. 2, no. 1/Januari, 2012.

[4] S. Surahman, "Dampak Globalisasi Media Terhadap Seni dan Budaya Indonesia," LONTAR J. Ilmu Komun., vol. 2, no. 1, 2017.

[5] M. I. Musa, "DAMPAK PENGARUH GLOBALISASI BAGI KEHIDUPAN BANGSA INDONESIA,” J. Pesona Dasar, vol. 3, no. 3, 2015.

[6] L. A. Jensen, J. J. Arnett, and J. McKenzie, "Globalization and cultural identity," in Handbook of identity theory and research, Springer, 2011, pp. 285-301.

[7] Y. Wang, "Globalization enhances cultural identity," Intercult. Commun. Stud., vol. 16, no. 1 , p. 83, 2007.

[8] A. Appadurai, "Disjuncture and difference in the global cultural economy," Theory, Cult. Soc., vol. 7, no. 2-3, pp. 295-310, 1990.

[9] A. L. Tsing, Friction: An ethnography of global connection. Princeton University Press, 2011.

[10] R. Bogdan and S. J. Taylor, "Introduction to qualitative methods: A phenomenological approach to the social sciences." New York: Wiley, 1975.

[11] L. J. Moleong, "Metodologi Kualitatif Edisi Revisi," Bandung PT. Remaja Rosdakarya, 2005.

[12] P. A. Damayanti, "Dinamika Perilaku 'Nakal' Anak Berambut Gimbal di Dataran Tinggi Dieng," 2012.

[13] S. Mutmainah, "Perilaku Sosial Anak Usia Dini Berambut Gimbal Di Daerah Dataran Tinggi Dieng Kabupaten Wonosobo,” Indones. J. Early Child. Educ. Stud., vol. 1, no. 1, 2012.

[14] A. Febriyanto, S. Riawanti, and B. Gunawan, "Mitos Rambut Gimbal: Identitas Budaya dan Komodifikasi di Dataran Tinggi Dieng," UMBARA Indones. J. Anthropol., vol. 2, no. $1,2018$.

[15] R. S. Soebalidinata, Cerita murwakala dan ruwatan di Jawa. Proyek Javanologi, Proyek Penelitian dan Pengkajian Kebudayaan Nusantara ..., 1984.

[16] B.W. Setyawan and K. Saddhono, "Eret traditional ceremony as representation of spirit of mutual cooperation among coastal communities". Adv. Sci. Let. vol. 23 no.10, pp 9991-9992, 2017 